\title{
Stimulation of glucose uptake in murine soleus muscle and adipocytes by 5-(4-phenoxybutoxy)psoralen (PAP-1) may be mediated by Kv1.5 rather than Kv1.3
}

$\mathrm{Kv} 1$ channels are shaker-related potassium channels that influence insulin sensitivity. Kv1.3 -- mice are protected from diet-induced insulin resistance and some studies suggest that Kv1.3 inhibitors provide similar protection. However, it is unclear whether blockade of Kv1.3 in adipocytes or skeletal muscle increases glucose uptake. There is no evidence that the related channel Kv1.5 has any influence on insulin sensitivity and its expression in adipose tissue has not been reported. PAP-1 is a selective inhibitor of Kv1.3, with 23-fold, 32-fold and 125fold lower potencies as an inhibitor of Kv1.5, Kv1.1 and Kv1.2 respectively. Soleus muscles from wild-type and genetically obese ob/ob mice were incubated with 2-deoxy[1- $\left.{ }^{14} \mathrm{C}\right]$-glucose for $45 \mathrm{~min}$ and formation of 2-deoxy[1- $\left.{ }^{14} \mathrm{C}\right]$-glucose-6-phosphate was measured. White adipocytes were incubated with D-[U- $\left.{ }^{14} \mathrm{C}\right]$-glucose for $1 \mathrm{~h}$. TNFalpha and II- 6 secretion from white adipose tissue pieces were measured by enzyme-linked-immunoassay. In the absence of insulin, a high concentration (3 $\mu \mathrm{M})$ of PAP-1 stimulated 2-deoxy[1-14C]-glucose uptake in soleus muscle of wild-type and obese mice by $30 \%$ and $40 \%$ respectively, and in adipocytes by $20 \%$ and $50 \%$ respectively. PAP- 1 also stimulated glucose uptake by adipocytes at the lower concentration of $1 \mu \mathrm{M}$, but at $300 \mathrm{nM}$, which is still 150-fold higher than its EC50 value for inhibition of the Kv1.3 channel, it had no effect. In the presence of insulin, PAP-1 (3 $\mu \mathrm{M})$ had a significant effect only in adipocytes from obese mice. PAP-1 $(3 \mu \mathrm{M})$ reduced the secretion of TNFalpha by adipose tissue but had no effect on the secretion of IL-6. Expression of Kv1.1, Kv1.2, Kv1.3 and Kv1.5 was determined by RT-PCR. Kv1.3 and Kv1.5 mRNA were detected in liver, gastrocnemius muscle, soleus muscle and white adipose tissue from wildtype and ob/ob mice, except that Kv1.3 could not be detected in gastrocnemius muscle, nor 
Kv1.5 in liver, of wild-type mice. Expression of both genes was generally higher in liver and muscle of $o b / o b$ mice compared to wild-type mice. Kv1.5 appeared to be expressed more highly than Kv1.3 in soleus muscle, adipose tissue and adipocytes of wild-type mice. Expression of $\mathrm{Kv1.2}$ appeared to be similar to that of $\mathrm{Kv1.3}$ in soleus muscle and adipose tissue, but Kv1.2 was undetectable in adipocytes. Kv1.1 could not be detected in soleus muscle, adipose tissue or adipocytes. We conclude that inhibition of Kv1 channels by PAP-1 stimulates glucose uptake by adipocytes and soleus muscle of wild-type and ob/ob mice, and reduces the secretion of TNFalpha by adipose tissue. However, these effects are more likely due to inhibition of Kv1.5 than to inhibition of Kv1.3 channels. 
1 Robert A. Ngala ${ }^{1}$, Mohamed S. Zaibi, Kenneth Langlands, Claire J. Stocker, Jonathan R.S. Arch,

2 Michael A. Cawthorne

3 Clore Laboratory, Buckingham Institute for Translational Medicine, University of Buckingham,

4 Buckingham, UK

$5{ }^{1}$ Current address: Department of Molecular Medicine, School of Medical Sciences, Kwame

6 Nkrumah University of Science and Technology Kumasi. Ghana

7 Corresponding author: Jonathan Arch, Clore laboratory, Buckingham Institute for Translational

8 Medicine, University of Buckingham, Hunter Street, Buckingham MK18 1EG, UK. Tel. +44

91280820306 jon.arch@buckingham.ac.uk 


\section{INTRODUCTION}

11 Kv1 channels are shaker-related, voltage-gated potassium channels (Gutman et al., 2003). It has

12 been proposed that compounds that block the Kv1.3 channel might be used in the treatment of

13 type 2 diabetes and obesity (Choi \& Hahn, 2010). Thus, a variant of the human Kv1.3 gene is

14 associated with low insulin sensitivity and impaired glucose tolerance (Tschritter et al., 2006),

15 whereas $\mathrm{Kv} 1.3^{-/}$mice were protected from diet-induced insulin resistance ( $\left.\underline{\mathrm{Xu} \text { et al., 2003 }}\right)$ and

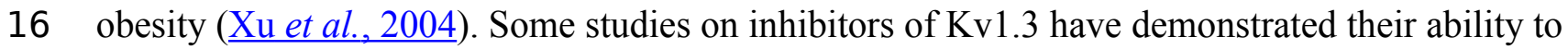

17 improve insulin sensitivity in mice (Xu et al., 2004, Upadhyay et al., 2013), but another has

18 failed to show any benefit (Straub et al., 2011).

19 In those studies in which improved insulin sensitivity has been shown, the tissues where the

20 inhibitors have their primary action are uncertain. Kv1.3 channels in liver, postganglionic

21 sympathetic neurons and brown adipose tissue are suggested targets (Upadhyay et al., 2013). It

22 is unclear whether white adipose tissue or skeletal muscle could be the primary site of action

23 because there is disagreement as to whether Kv1.3 is expressed, particularly at the protein level,

24 in these tissues (Grande et al., 2003, Li et al., 2006, Straub et al., 2011, Upadhyay et al., 2013).

25 Nevertheless, the Kv1.3 inhibitor margatoxin decreased TNF $\alpha$ secretion by white adipose tissue

26 from genetically obese $(o b / o b)$ mice $(\underline{\mathrm{Xu} \text { et } a l ., 2004})$, and administration of the highly selective

27 Kv1.3 inhibitor ShK-186 for 45 days to mice fed on an obesity-inducing diet reduced TNF $\alpha$

28 mRNA in visceral adipose tissue (Upadhyay et al., 2013). The target for the latter effect might be

29 Kv1.3 channels in inflammatory cells, such as macrophages. Decreased inflammation of adipose

30 tissue, including decreased secretion of TNF $\alpha$, would be expected to improve insulin sensitivity

31 (Calle \& Fernandez, 2012). 
32 As part of an investigation into the potential of Kv1.3 inhibitors for the treatment of type 2

33 diabetes, we have studied the effect of 5-(4-phenoxybutoxy)psoralen (PAP-1) on glucose uptake

34 in white adipocytes and soleus muscle, and TNF $\alpha$ secretion by white adipocytes from wild-type

35 and $o b / o b$ mice. PAP-1 is a selective inhibitor of Kv1.3, being at least 23 -fold selective as an

36 inhibitor of Kv1.3 over other Kv1-family channels and 500-fold selective over Kv2.1, Kv3.1,

$37 \mathrm{Kv} 3.2$ and Kv4.2 channels ( schmitz et al., 2005). We report that a concentration of PAP-1 that is

38 not selective for Kv1.3 stimulated glucose uptake and reduced TNF $\alpha$ secretion, but a lower

39 concentration was ineffective, in agreement with the results of others (Beeton et al., 2006, $\underline{\text { Straub }}$

40 et al., 2011). This raised the question of the target for the non-selective concentration of PAP-1

41 and led us to investigate the expression of Kv1.1, Kv1.2, Kv1.3 and Kv1.5 in mouse skeletal

42 muscle and white adipose tissue. Kv1.5 is identified as a candidate mediator of the effects of

43 PAP-1 on glucose uptake. 


\section{MATERIALS AND METHODS}

\section{Materials}

46 All materials, including PAP-1 (>98\% purity), were obtained from Sigma-Aldrich, Poole, UK,

47 unless otherwise stated.

\section{Animals}

49 Housing and procedures were conducted in accordance with the UK Government Animal 50 (Scientific procedures) Act 1986 and approved by the University of Buckingham Ethical review

51 Board. C57B1/6 and ob/ob mice (Harlan, Bicester, UK), aged 5-6 weeks, were fed standard

52 laboratory chow ad libitum and euthanized 3-4 hours after the onset of day light cycle, by a UK

53 Government Animal Scientific Act 1986 schedule 1 method.

\section{RT-PCR}

55 Tissues isolated from wild-type and $o b / o b$ female C57Bl/6 mice were homogenized in Tri-reagent

56 using a ribolyser and total RNA prepared using Qiagen ${ }^{\mathrm{TM}}$ minicolumns according to the

57 manufacturer's instructions. One $\mu \mathrm{g}$ total RNA was reverse-transcribed using avian reverse

58 transcriptase and random priming in a $50 \mu \mathrm{l}$ reaction. Two $\mu \mathrm{l}$ cDNA was subsequently used per

$5950 \mu \mathrm{l}$ PCR reaction as standard. GAPDH was chosen as the housekeeping genes because it

60 showed consistent $\mathrm{C}_{\mathrm{T}}$ values in adipose tissue, adipocytes and soleus muscle. Gene expression

61 assays were obtained from Applied Biosystems Assay-on-Demand predesigned and optimized 62 assays.

63 Subsequently, tissues were isolated from wild-type female C57Bl/6 mice. Total RNA was

64 extracted and RT PCR performed by Real Time PCR using optimized Assay-on-Demand 65 (Applied Biosystems) primers and probes for Kv1.1, 1.2, 1.3 and 1.5, relative to an endogenous 
66 GAPDH control (Wargent et al., 2013). Expression of each potassium channel was calculated

67 relative to expression of GAPDH in each sample and then the expression levels of Kv1.2 and

$68 \mathrm{Kv} 1.5$ were expressed relative to Kv1.3 in the same tissue (Wargent et al 2013). Multiple Kv

69 channels were not run in the same PCR reaction in order to prevent competition between the

70 cDNA templates for the amplification reactants and to optimize reaction efficiency.

\section{2-Deoxyglucose uptake by soleus muscle}

72 Uptake of 2-deoxyglucose by the soleus muscle was measured by a method that we have

73 described previously (gala et al., 2008). Soleus muscles were dissected from both hind legs of

74 wild-type and ob/ob C57B1/6 male mice. Distal and proximal tendons were tied under resting

75 tension to stainless steel clips and pre-incubated for $60 \mathrm{~min}$ in Krebs-Henseleit bicarbonate buffer

76 that contained $10 \mathrm{mM}$ 4-(2-hydroxyethyl)-1-piperazineethanesulfonic acid (HEPES), $5.5 \mathrm{mM}$

77 glucose and $0.14 \%(\mathrm{w} / \mathrm{v})$ fatty acid-free bovine serum albumin (BSA) at $\mathrm{pH} 7.4$ and $37^{\circ} \mathrm{C}$. The

78 buffer had been gassed previously with $95 \% \mathrm{O}_{2}: 5 \% \mathrm{CO}_{2}$. They were then incubated for $45 \mathrm{~min}$ in

79 fresh medium that also contained 2-deoxy $\left[1-{ }^{14} \mathrm{C}\right]$ glucose $\left(56 \mathrm{mCi} \mathrm{mmol}^{-1} ; 0.1 \mu \mathrm{Ci} \mathrm{ml}^{-1}\right)$ and

80 glucose $(5.5 \mathrm{mM})$, with or without insulin ( $10 \mathrm{nM}$ for wild-type mice and $100 \mathrm{nM}$ for $o b / o b$

81 mice $)$ and PAP-1 $(3 \mu \mathrm{M})$ or a combination of insulin and PAP-1.

82 At the end of the incubation, the muscles were digested with $1 \mathrm{M} \mathrm{NaOH}$ and the digest was

83 neutralised with $1 \mathrm{M} \mathrm{HCl}$. One portion of the mixture was treated with 2.5 volumes of $6 \%(\mathrm{w} / \mathrm{v})$

84 perchloric acid to precipitate out proteins, leaving supernatant that contained both 2-

85 deoxyglucose and 2-deoxyglucose-6-phosphate. Another portion was treated with 2.5 volumes of

$862.68 \%(\mathrm{w} / \mathrm{v}) \mathrm{Ba}(\mathrm{OH})_{2}$ and $2.51 \%(\mathrm{w} / \mathrm{v}) \mathrm{ZnSO}_{4}$ to precipitate out 2-deoxyglucose-6-phosphate.

87 Radioactivity incorporated into 2-deoxyglucose-6-phosphate was obtained from the difference 
88 between that in the two supernatants. 2-Deoxyglucose uptake was calculated by dividing

89 radioactivity in 2-deoxyglucose-6-phosphate by the specific activity of 2-deoxyglucose.

\section{Glucose uptake by adipocytes}

91 Adipocytes were prepared from the parametrial fat pads of wild-type and $o b / o b$ female mice by a

92 method that we have described previously (Zaibi et al., 2010). Tissue was minced and digested

93 with collagenase type II in Krebs-Ringer HEPES buffer containing $10 \mathrm{mM}$ HEPES, $1 \%$ bovine

94 serum albumin (fraction V), $2.5 \mathrm{mM} \mathrm{CaCl}_{2}, 5.5 \mathrm{mM}$ glucose and $200 \mathrm{nM}$ adenosine at $\mathrm{pH} 7.4$ and

$9537^{\circ} \mathrm{C}$. It was filtered through $250-300 \mu \mathrm{m}$ nylon mesh. The infranatant was removed and the

96 floating layer of adipocytes was washed four times with a fresh buffer. Adipocytes were

97 concentrated to $40 \%$ of final volume of Krebs-Ringer HEPES buffer containing 5\% BSA and 0.3

$98 \mathrm{mM}$ glucose and pre-incubated for 45 min under $95 \% \mathrm{O}_{2}: 5 \% \mathrm{CO}_{2}$ before dispensing them into

$99300 \mu 1$ polyethylene tubes for measurement of glucose uptake.

100 Glucose transport was measured as described previously (Kashiwagi, Huecksteadt \& Foley,

101 1983). Adipocytes were incubated in Krebs-Ringer HEPES buffer containing BSA, $0.3 \mathrm{mM}$

102 glucose and $\mathrm{D}-\left[\mathrm{U}-{ }^{14} \mathrm{C}\right]$ glucose $(0.2 \mu \mathrm{mol} / 1 ; 0.2 \mu \mathrm{Ci} / \mathrm{ml})$, for $1 \mathrm{~h}$ at $37^{\circ} \mathrm{C}$ in the absence or

103 presence of different concentrations of PAP-1 and insulin. The reaction was stopped by

104 separation of the cells through silicone oil and radioactivity in the cells was measured.

105 Extracellular space was measured in parallel incubations using D-[U- $\left.{ }^{14} \mathrm{C}\right]$ sucrose. Secretion is

106 expressed per mg protein, determined using a method based on the Lowry assay (Bio-Rad, Hemel

107 Hempstead, UK) or per g cells.

\section{TNF $\alpha$ and IL-6 secretion}

109 Adipose tissue from $o b / o b$ and wild-type female mice was minced into pieces weighing about $110200 \mathrm{mg}$ and added to $0.3 \mathrm{ml}$ Dulbecco's modified Eagle's medium and Ham's F-12 in a 1:1 
111 mixture (both from Invitrogen, Paisley, UK), supplemented with $0.5 \%(\mathrm{w} / \mathrm{v})$ endotoxin-free

112 BSA. The incubation medium also contained $1 \mathrm{nM}$ T3 and $5 \mathrm{mM}$ glutamine. The plates were

113 incubated with or without PAP-1 $(3 \mu \mathrm{M})$ for $30 \mathrm{~min}$. TNF $\alpha$ and IL-6 in the culture medium was

114 assayed using murine ELISA kits (from Diaclone, Besançon, France for TNF; from Invitrogen for

115 IL-6), following the manufacturer's instructions. Secretion is expressed per mg protein,

116 determined using the Lowry assay.

\section{Statistical analysis}

118 Glucose uptake was calculated assuming that 2-deoxyglucose and glucose are not distinguished 119 by uptake mechanisms. Data were analyzed by one- or two-way ANOVA followed by Fisher's

120 least significant difference test, as described in the figure legends, using GraphPad Prism version

1215 (GraphPad software, San Diego CA, USA). Results are expressed as means \pm SEM.

\section{RESULTS}

\section{Glucose uptake in soleus muscle}

124 Insulin $(10 \mathrm{nM})$ and PAP-1 $(3 \mu \mathrm{M})$ stimulated 2-deoxyglucose uptake in soleus muscle from both

125 wild-type and ob/ob mice (Fig. 1). The combination of insulin and PAP-1 also stimulated uptake

126 compared to baseline in muscle from both wild-type and ob/ob mice $(P<0.001)$, but it did not

127 have a significantly greater effect than either insulin or PAP-1 alone.

\section{Glucose uptake in Adipocytes}

129 PAP-1 $(3 \mu \mathrm{M})$ stimulated glucose in adipocytes from both wild-type and obese mice in the

130 absence of insulin. In the presence of insulin at a range of concentrations, its effect was

131 significant only in adipocytes from $o b / o b$ mice (Fig 2). In the absence of PAP-1, insulin

132 stimulated uptake at concentrations of $0.5 \mathrm{nM}$ and higher. The combination of insulin and PAP-1 
133 stimulated uptake compared to baseline, but insulin did not stimulate glucose uptake significantly

134 in the presence of PAP-1. A concentration-response curve conducted using adipocytes from wild-

135 type mice in the absence of insulin showed significant effects of PAP-1 at 1 and $3 \mu \mathrm{M}$, but not at

136 lower concentrations (Fig.3).

137 TNF $\alpha$ and IL-6 secretion

138 PAP-1 $(3 \mu \mathrm{M})$ suppressed the secretion of TNF $\alpha$ by $50 \%$ in adipocytes from both wild-type and

$139 o b / o b$ mice (Fig.4). PAP-1 did not affect IL-6 secretion (results not shown). Surprisingly,

140 secretion of TNF $\alpha$ from $o b / o b$ adipocytes was lower than from wild-type adipocytes. Others

141 have found a higher concentration of TNF $\alpha$ in adipocytes from $o b / o b$ compared to wild-type

142 adipocytes (Galvez, San Martin \& Rodriguez, 2009).

\section{Expression of Kv1mRNA}

144 Using reverse transcription PCR, Kv1.3 mRNA was detected in liver, gastrocnemius muscle,

145 soleus muscle and parametrial white adipose tissue of female wild-type and $o b / o b$ mice, except

146 that expression was not significantly above baseline in gastrocnemius muscle from wild-type

147 mice (Fig.5A). Expression was higher in liver, gastrocnemius muscle and soleus muscle, but not

148 adipose tissue, of $o b / o b$ mice compared to wild-type mice. Kv1.5 mRNA was detected in liver,

149 gastrocnemius muscle, soleus muscle and parametrial white adipose tissue of female wild-type

150 and $o b / o b$ mice, except that expression could not be detected in livers from wild-type mice (Fig.

151 5B). Expression was higher in liver and soleus muscle of $o b / o b$ mice compared to wild-type

152 mice.

153 After it was found that PAP-1 did not stimulate glucose uptake by adipocytes at concentrations

154 that should be sufficient to activate Kv1.3, Real-Time PCR was used to detect mRNA for Kv1.1,

$155 \mathrm{Kv1.2,} \mathrm{Kv1.3} \mathrm{and} \mathrm{Kv1.5} \mathrm{in} \mathrm{each} \mathrm{of} \mathrm{adipose} \mathrm{tissue,} \mathrm{adipocytes} \mathrm{and} \mathrm{soleus} \mathrm{muscle.} \mathrm{Assuming} \mathrm{PCR}$ 
156 reaction efficiencies of 1.0 for each gene, Kv1.5 was 30-, 15- and 78-fold more highly expressed

157 than Kv1.3 in adipose tissue, adipocytes and soleus muscle respectively. Kv1.2 mRNA could not

158 be detected in adipocytes and appeared to have lower expression than Kv1.3 in adipose tissue

159 (Fig.6). Kv1.1 could not be detected in adipose tissue, adipocytes or soleus muscle. 


\section{DISCUSSION}

161 A variety of evidence suggests that inhibition of Kv1.3 potassium channels might be effective in

162 the treatment of insulin resistance, and thereby of type 2 diabetes (Choi \& Hahn, 2010, Upadhyay

163 et al., 2013). This includes the finding that margatoxin, which inhibits members of the Kv1

164 family, including Kv1.3, lowered blood glucose in wild-type but not $\mathrm{Kv} 1.3^{-/ 2}$ mice ( $\underline{\mathrm{Xu} \text { et al., }}$

165 2004). The authors linked this finding to the demonstration that margatoxin inhibited the

166 secretion of TNF $\alpha$ and IL- 6 by isolated adipocytes in adipose tissue and skeletal muscle after it

167 was administered to wild-type but not $\mathrm{Kv} 1.3^{-/-}$mice. The tissues that contain the Kv1.3 channels

168 at which the inhibitors exert their initial effects have not been well-defined, however.

169 We investigated whether the initial effects of Kv1.3 inhibitors might be on Kv1.3 channels in

170 adipocytes or skeletal muscle using PAP-1. PAP-1 inhibits Kv1.3 with 33-fold selectivity over

171 Kv1.1, 125-fold selectivity over Kv1.2 and 23-fold selectivity over Kv1.5 (Schmitz et al., 2005).

172 Inhibition of $\mathrm{K}$ channels might be expected to lead to cell depolarization and an increased

173 demand for energy. We found that PAP-1 at the high concentration of $3 \mu \mathrm{M}$ stimulated glucose

174 uptake in the absence of insulin in isolated soleus muscle and adipocytes from both wild-type and

$175 a b / o b$ mice. PAP-1 also stimulated glucose uptake in the presence of a range of concentrations of

176 insulin in adipocytes from $o b / o b$ mice. The same concentration of PAP-1 $(3 \mu \mathrm{M})$ also reduced

177 the secretion of TNF $\alpha$ by adipocytes, potentially consistent with the suggestion of others ( $\underline{\mathrm{Xu}}$ et

178 al.,2004) that this is a mechanism by which blockade of Kv1.3 improves insulin sensitivity.

179 However, when we investigated the concentration-response curve for the effect of PAP-1 on

180 glucose uptake, we found that, whilst $1 \mu \mathrm{M}$ was effective, a concentration of $300 \mathrm{nM}$, which is

181 still 150-fold higher than its $\mathrm{EC}_{50}$ value for blockade of murine Kv1.3 (Schmitz et al., 2005), had

182 no effect on glucose uptake. 
183 These experiments were conducted using tissues from female mice, except that soleus muscles

184 from male mice were used for studying glucose uptake. These choices were in line with our

185 previous work, allowing more accurate quality control by comparison with our historic data.

186 Most studies of the effects of Kv1.3 inhibitors on metabolism have been conducted using male

187 mice, but two studies have shown that deletion of the Kv1.3 gene has similar metabolic effects in

188 male and female mice (Xu et al., 2003, Tucker, Overton \& Fadool, 2008).

189 Our results are consistent with a report that PAP-1 failed to lower blood glucose or enhance the

190 glucose lowering effect of insulin when administered as a single dose or over five days to $o b / o b$

191 or $d b / d b$ mice in amounts that gave blood levels that would selectively block Kv1.3. Moreover,

$19210 \mathrm{nM}$ PAP-1, a concentration fivefold higher than its $\mathrm{IC}_{50}$ value for inhibition of $\mathrm{Kv} 1.3$ channels,

193 did not alter $\mathrm{K}^{+}$currents in a human skeletal muscle cell line or glucose uptake in mouse 3T3-L1

194 adipocytes (Straub et al. 2011). Similarly, margatoxin did not stimulate glucose utilization by rat

195 epididymal or mesenteric adipocytes (Beeton et al.,2006) when used at concentrations (1 or 100

$196 \mathrm{nM}$ ) well above its $\mathrm{EC}_{50}$ value (30 pM) for inhibition of Kv1.3 (Garcia-Calvo et al., 1993).

197 Upadhyay et al. (Upadhyay et al., 2013) have reported that the highly selective Kv1.3 inhibitor

198 ShK-186 reduces obesity and hyperglycemia in mice fed on an obesogenic diet, but they too rule

199 out an involvement of white adipocyte or skeletal muscle Kv1.3 channels, mainly because ShK-

200186 did not stimulate glucose uptake by white adipose tissue or skeletal muscle. ShK-186

201 doubled glucose uptake in brown adipose tissue, a site of high glucose uptake and uncoupled

202 oxidative phosphorylation, making this a more likely explanation for the anti-obesity and anti-

203 hyperglycemic effects of ShK-186, in their view. The same group had previously reported that

204 ShK-186 also failed to stimulate glucose uptake by rat white adipocytes (Beeton et al., 2006).

205 Although we do not believe that PAP-1 affected glucose uptake by inhibiting Kv1.3, we did 206 detect Kv1.3 mRNA in murine adipose tissue and skeletal muscle (and also liver). Others appear 
207 to disagree as to whether Kv1.3 protein is expressed in murine adipose tissue, but this may be

208 because one group used isolated epididymal adipocytes (Li et al., 2006) and the other visceral

209 adipose tissue (Upadhyay et al., 2013). No Kv1.3 protein was detected in murine skeletal muscle

210 (Upadhyay et al., 2013) or in samples of adipose tissue and skeletal muscle from two normal and

211 two type 2 diabetic human subjects (Straub et al., 2011). One possible interpretation of these

212 reports and our findings is that the expression of Kv1.3 is very low in adipose tissue and skeletal

213 muscle, and is sometimes undetectable at the protein level, despite being detectable at the mRNA

214 level. We found more Kv1.3 mRNA in tissues from $o b / o b$ than wild-type mice, except for white

215 adipose tissue, but given the relative amounts of adipose tissue in the wild-type and obese

216 animals, the total amount of Kv1.3 mRNA in adipose tissue per animal may be higher in the

$217 a b / o b$ mice. We also found more Kv1.5 mRNA in liver and soleus muscle of $o b / o b$ compared to

218 lean mice. These results would be consistent with expression of either channel contributing to

219 insulin resistance in $o b / o b$ mice.

220 Levels of Kv1.5 mRNA appeared much higher than those of Kv1.3 in both adipocytes and soleus

221 muscle. It is well-established that Kv1.5 is expressed in skeletal muscle (Kang et al., 2009) but

222 its expression in adipose tissue or adipocytes has not been reported. We cannot exclude the

223 possibility that our results are influenced to some extent by the PCR reaction efficiency differing

224 between genes, but this seems unlikely to alter our conclusion that the expression of Kv1.5 was

225 much higher than that of Kv1.3 or Kv1.2 (Irwin et al., 2012). In any event, irrespective of the

226 precise differences in expression of the Kv genes, our findings raise the possibility that Kv1.5

227 was the channel that PAP-1 inhibited to stimulate glucose uptake and inhibit TNF $\alpha$ secretion. If

228 so, Kv1.5 inhibitors might have potential in the treatment of type 2 diabetes. PAP-1 has been

229 reported to inhibit Kv1.5 with an $\mathrm{EC}_{50}$ value of $45 \mathrm{nM}$ (Schmitz et al., 2005), but it failed to

230 stimulate glucose uptake in adipocytes when present at a concentration of $300 \mathrm{nM}$. The 6.7-fold 
231 lower $\mathrm{EC}_{50}$ value of $45 \mathrm{nM}$ was, however, measured with $\mathrm{Kv} 1.5$ from a different species and

232 under very different conditions: it was obtained by applying depolarizing pulses to mouse

233 erythroleukaemia (MEL) cells stably transfected with human Kv1.5 and measuring the reduction

234 in area under the current curve (Grissmer et al., 1994). By contrast, no depolarizing stimulus was

235 applied in our work and we used mouse tissue. Whilst the $\mathrm{EC}_{50}$ value of $2 \mathrm{nM}$ for PAP-1 at Kv1.3

236 was also determined by an electrophysiological technique, it did use murine Kv1.3 ( $\underline{\text { Schmitz et }}$

237 al.,2005), and it is less likely that the much higher (150-fold) discrepancy between this value and

238 the minimum effective dose of PAP-1 for stimulation of glucose uptake can be explained in terms

239 of the different test systems. PAP-1 is less potent at Kv1.2 $\left(\mathrm{EC}_{50}=250 \mathrm{nM}\right)$ than Kv1.5 ( $\underline{\text { Schmitz }}$

240 et al., 2005), and Kv1.2 mRNA could not be detected in adipocytes using Real Time RCR, ruling

241 it out as a candidate target for PAP-1 in this tissue. We cannot rule out the possibility that Kv1.4,

$242 \mathrm{Kv} 1.6$ or Kv1.7 could be the targets of PAP-1 in adipocytes and skeletal muscle, but Kv1.4 is

243 poorly expressed in human adipocytes (You et al., 2013), and $100 \mathrm{nM}$ margatoxin did not

244 stimulate glucose uptake in rat epididymal adipocytes (Beeton et al., 2006), despite having an

$245 \mathrm{EC}_{50}$ value for inhibition of Kv1.5 of $5 \mathrm{nM}$ (Garcia-Calvo et al., 1993).

246 We therefore conclude that although Kv1.3 mRNA could be detected in murine white adipose

247 tissue, white adipocytes and red skeletal muscle, inhibition of Kv1.3 does not directly affect

248 glucose uptake in white adipocytes or skeletal muscle. Blockade of Kv1.5 channels in white

249 adipocytes or skeletal muscle might, however, stimulate glucose uptake. Studies using novel

$250 \mathrm{Kv} 1.5$ inhibitors might be informative, but their selectivities have been given only relative to

251 other cardiac K channels and not to other Kv1 channels (Ford et al., 2013, Pavri et al., 2012). We

252 do not exclude the possibility that compounds might be useful in the treatment of obesity and

253 insulin resistance, by inhibiting Kv1.3 in other tissues. 


\section{ACKNOWLEDGEMENTS}

255 The authors are grateful to Dr Claire Cornick for assisting with the experiments, to Professor

256 John Clapham for discussion of the manuscript and to Mrs Anita Roberts for help with the

257 husbandry of the animals. 
259

260

261

262

263

264

265

266

267

268

269

270

271

272

273

274

275

276

277

278

279

280

281

282

283

284

285

286

287

288

289

290

291

292

293

294

295

296

297

298

299

300

301

302

303

304

305

306

Beeton C, Wulff H, Standifer NE, Azam P, Mullen KM, Pennington MW, Kolski-Andreaco A, Wei E, Grino A, Counts DR, Wang PH, LeeHealey CJ, B SA, Sankaranarayanan A, Homerick D, Roeck WW, Tehranzadeh J, Stanhope KL, Zimin P, Havel PJ, Griffey S, Knaus HG, Nepom GT, Gutman GA, Calabresi PA, Chandy KG (2006). Kv1.3 channels are a therapeutic target for T cell-mediated autoimmune diseases. Proc Natl Acad Sci U S A 103: 17414-17419.

Calle MC, Fernandez ML (2012). Inflammation and type 2 diabetes. Diabetes Metab 38: 183-191.

Choi BH, Hahn SJ (2010). Kv1.3: a potential pharmacological target for diabetes. Acta Pharmacol Sin 31: 1031-1035.

Ford J, Milnes J, Wettwer E, Christ T, Rogers M, Sutton K, Madge D, Virag L, Jost N, Horvath Z, Matschke K, Varro A, Ravens U (2013). Human electrophysiological and pharmacological properties of XEN-D0101: a novel atrial-selective Kv1.5/IKur inhibitor. J Cardiovasc Pharmacol 61: 408-415.

Galvez BG, San Martin N, Rodriguez C (2009). TNF-alpha is required for the attraction of mesenchymal precursors to white adipose tissue in Ob/ob mice. PLoS One 4: e4444.

Garcia-Calvo M, Leonard RJ, Novick J, Stevens SP, Schmalhofer W, Kaczorowski GJ, Garcia ML (1993). Purification, characterization, and biosynthesis of margatoxin, a component of Centruroides margaritatus venom that selectively inhibits voltage-dependent potassium channels. J Biol Chem 268: 18866-18874.

Grande M, Suarez E, Vicente R, Canto C, Coma M, Tamkun MM, Zorzano A, Guma A, Felipe A (2003). Voltage-dependent K+ channel beta subunits in muscle: differential regulation during postnatal development and myogenesis. J Cell Physiol 195: 187-193.

Grissmer S, Nguyen AN, Aiyar J, Hanson DC, Mather RJ, Gutman GA, Karmilowicz MJ, Auperin DD, Chandy KG (1994). Pharmacological characterization of five cloned voltage-gated $\mathrm{K}+$ channels, types Kv1.1, 1.2, $1.3,1.5$, and 3.1 , stably expressed in mammalian cell lines. Mol Pharmacol 45: 1227-1234.

Gutman GA, Chandy KG, Adelman JP, Aiyar J, Bayliss DA, Clapham DE, Covarriubias M, Desir GV, Furuichi K, Ganetzky B, Garcia ML, Grissmer S, Jan LY, Karschin A, Kim D, Kuperschmidt S, Kurachi Y, Lazdunski M, Lesage F, Lester HA, McKinnon D, Nichols CG, O'Kelly I, Robbins J, Robertson GA, Rudy B, Sanguinetti M, Seino S, Stuehmer W, Tamkun MM, Vandenberg CA, Wei A, Wulff H, Wymore RS (2003). International Union of Pharmacology. XLI. Compendium of voltage-gated ion channels: potassium channels. Pharmacological Reviews 55: 583-586.

Irwin PL, Nguyen LH, Chen CY, Uhlich GA, Paoli GC (2012). A method for correcting standard-based real-time PCR DNA quantitation when the standard's polymerase reaction efficiency is significantly different from that of the unknown's. Anal Bioanal Chem 402: 2713-2725.

Kang LS, Kim S, Dominguez JM, 2nd, Sindler AL, Dick GM, Muller-Delp JM (2009). Aging and muscle fiber type alter K+ channel contributions to the myogenic response in skeletal muscle arterioles. J Appl Physiol (1985) 107: 389-398. 
Kashiwagi A, Huecksteadt TP, Foley JE (1983). The regulation of glucose transport by CAMP stimulators via three different mechanisms in rat and human adipocytes. J Biol Chem 258: 13685-13692.

Li Y, Wang P, Xu J, Desir GV (2006). Voltage-gated potassium channel Kv1.3 regulates GLUT4 trafficking to the plasma membrane via a Ca2+-dependent mechanism. Am J Physiol Cell Physiol 290: C345-351.

Ngala RA, O'Dowd J, Wang SJ, Agarwal A, Stocker C, Cawthorne MA, Arch JR (2008). Metabolic responses to BRL37344 and clenbuterol in soleus muscle and $\mathrm{C} 2 \mathrm{C} 12$ cells via different atypical pharmacologies and $\beta_{2}$-adrenoceptor mechanisms. BrJ Pharmacol 155: 395-406.

Pavri BB, Greenberg HE, Kraft WK, Lazarus N, Lynch JJ, Salata JJ, Bilodeau MT, Regan CP, Stump G, Fan L, Mehta A, Wagner JA, Gutstein DE, Bloomfield D (2012). MK-0448, a specific Kv1.5 inhibitor: safety, pharmacokinetics, and pharmacodynamic electrophysiology in experimental animal models and humans. Circ Arrhythm Electrophysiol 5: 1193-1201.

Schmitz A, Sankaranarayanan A, Azam P, Schmidt-Lassen K, Homerick D, Hansel W, Wulff H (2005). Design of PAP-1, a selective small molecule Kv1.3 blocker, for the suppression of effector memory T cells in autoimmune diseases. Mol Pharmacol 68: 1254-1270.

Straub SV, Perez SM, Tan B, Coughlan KA, Trebino CE, Cosgrove P, Buxton JM, Kreeger JM, Jackson VM (2011). Pharmacological inhibition of KV1.3 fails to modulate insulin sensitivity in diabetic mice or human insulin-sensitive tissues. Am J Physiol Endocrinol Metab 301: E380-390.

Tschritter O, Machicao F, Stefan N, Schafer S, Weigert C, Staiger H, Spieth C, Haring HU, Fritsche A (2006). A new variant in the human Kv1.3 gene is associated with low insulin sensitivity and impaired glucose tolerance. J Clin Endocrinol Metab 91: 654-658.

Tucker K, Overton JM, Fadool DA (2008). Kv1.3 gene-targeted deletion alters longevity and reduces adiposity by increasing locomotion and metabolism in melanocortin-4 receptor-null mice. Int J Obes (Lond) 32: 1222-1232.

Upadhyay SK, Eckel-Mahan KL, Mirbolooki MR, Tjong I, Griffey SM, Schmunk G, Koehne A, Halbout B, ladonato S, Pedersen B, Borrelli E, Wang PH, Mukherjee J, Sassone-Corsi P, Chandy KG (2013). Selective Kv1.3 channel blocker as therapeutic for obesity and insulin resistance. Proc Natl Acad Sci U S A 110: E2239-2248.

Wargent ET, O'Dowd JF, Zaibi MS, Gao D, Bing C, Trayhurn P, Cawthorne MA, Arch JR, Stocker CJ (2013). Contrasts between the effects of zinc-alpha2glycoprotein, a putative beta3/2-adrenoceptor agonist and the beta3/2adrenoceptor agonist BRL35135 in C57BI/6 (ob/ob) mice. J Endocrinol 216: 157-168.

Xu J, Koni PA, Wang P, Li G, Kaczmarek L, Wu Y, Li Y, Flavell RA, Desir GV (2003). The voltage-gated potassium channel Kv1.3 regulates energy homeostasis and body weight. Hum Mol Genet 12: 551-559.

Xu J, Wang P, Li Y, Li G, Kaczmarek LK, Wu Y, Koni PA, Flavell RA, Desir GV (2004). The voltage-gated potassium channel Kv1.3 regulates peripheral insulin sensitivity. Proc Natl Acad Sci U S A 101: 3112-3117.

You MH, Song MS, Lee SK, Ryu PD, Lee SY, Kim DY (2013). Voltage-gated K+ channels in adipogenic differentiation of bone marrow-derived human mesenchymal stem cells. Acta Pharmacol Sin 34: 129-136.

Zaibi MS, Stocker CJ, O'Dowd J, Davies A, Bellahcene M, Cawthorne MA, Brown AJ, Smith DM, Arch JR (2010). Roles of GPR41 and GPR43 in leptin 

secretory responses of murine adipocytes to short chain fatty acids. FEBS Lett 584: 2381-2386. 


\section{Figure 1}

\section{Effect of PAP-1 on glucose uptake in soleus muscles of male (A) wild-type and (B) ob/ob C57BI6 mice.}

Muscles were treated with insulin (wild-type, $10 \mathrm{nM}$; ob/ob, $100 \mathrm{nM}$ ) or PAP-1 (3 microM) alone, or the combination of insulin and PAP-1. $n=8$ mice per group for all columns. Data for each genotype were analyzed by one-way ANOVA followed by Fisher's least significant difference test. ${ }^{*} P<0.05$ for effect of PAP-1 compared to controls (Con). ${ }^{\dagger} P<0.05$ for effect of insulin (Ins) compared to controls. ${ }^{\ddagger \ddagger \ddagger} P<0.001$ for the effect of the combination of PAP-1 and insulin compared to the absence of both compounds (Con). Note that in both wild-type and ob/ob mice, glucose uptake in the presence of the combination of PAP-1 and insulin was not significantly greater than in the absence of one of the compounds. 
A

Wild-type mice

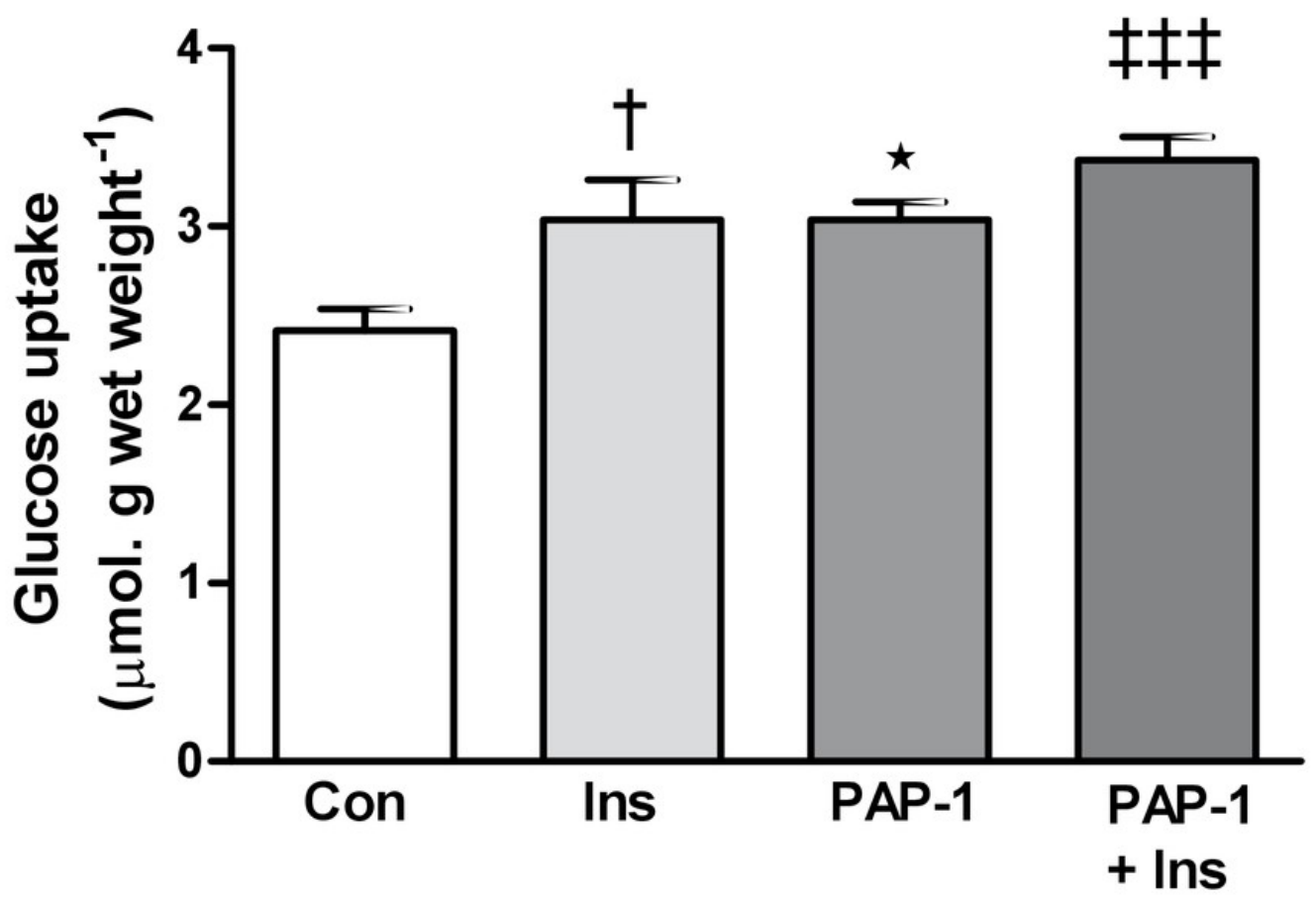

B

ob/ob mice

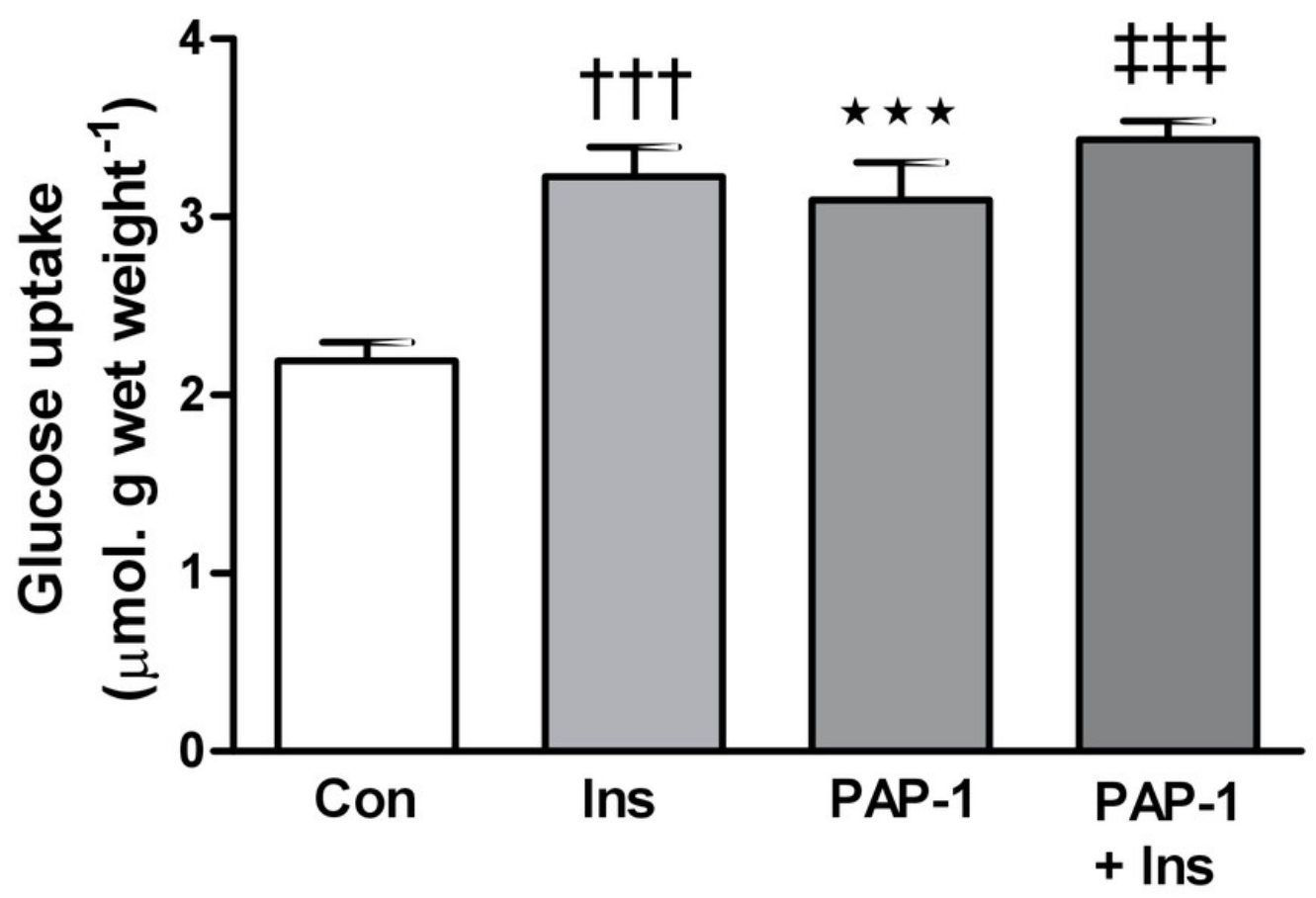




\section{Figure 2}

Effect of PAP-1 on glucose uptake in adipocytes of female (A) wild-type and (B) ob/ob C57Bl6 mice.

Adipocytes were treated with insulin, PAP-1 (P, 3 microM ) alone, or a combination of insulin and PAP-1. $n=8$ mice per group for all columns. Data for each genotype were analyzed by two-way ANOVA (sources of variation: PAP-1 and insulin concentrations), followed by Fisher's least significant difference test, first for the paired columns at the same concentration of insulin, and second to test for an effect of insulin compared to the value obtained in the absence of insulin but in the presence of the same concentration (0 or 3 microM) of PAP-1. ${ }^{*} P<0.05$; ${ }^{* \star} P<0.001$ for effect of PAP-1 compared to controls at the same concentration of insulin (C). ${ }^{\dagger} P<0.05 ;{ }^{\dagger \dagger} P<0.01 ;{ }^{\dagger \dagger} P<0.001$ for effect of insulin compared to no insulin at the same concentration of PAP-1. 


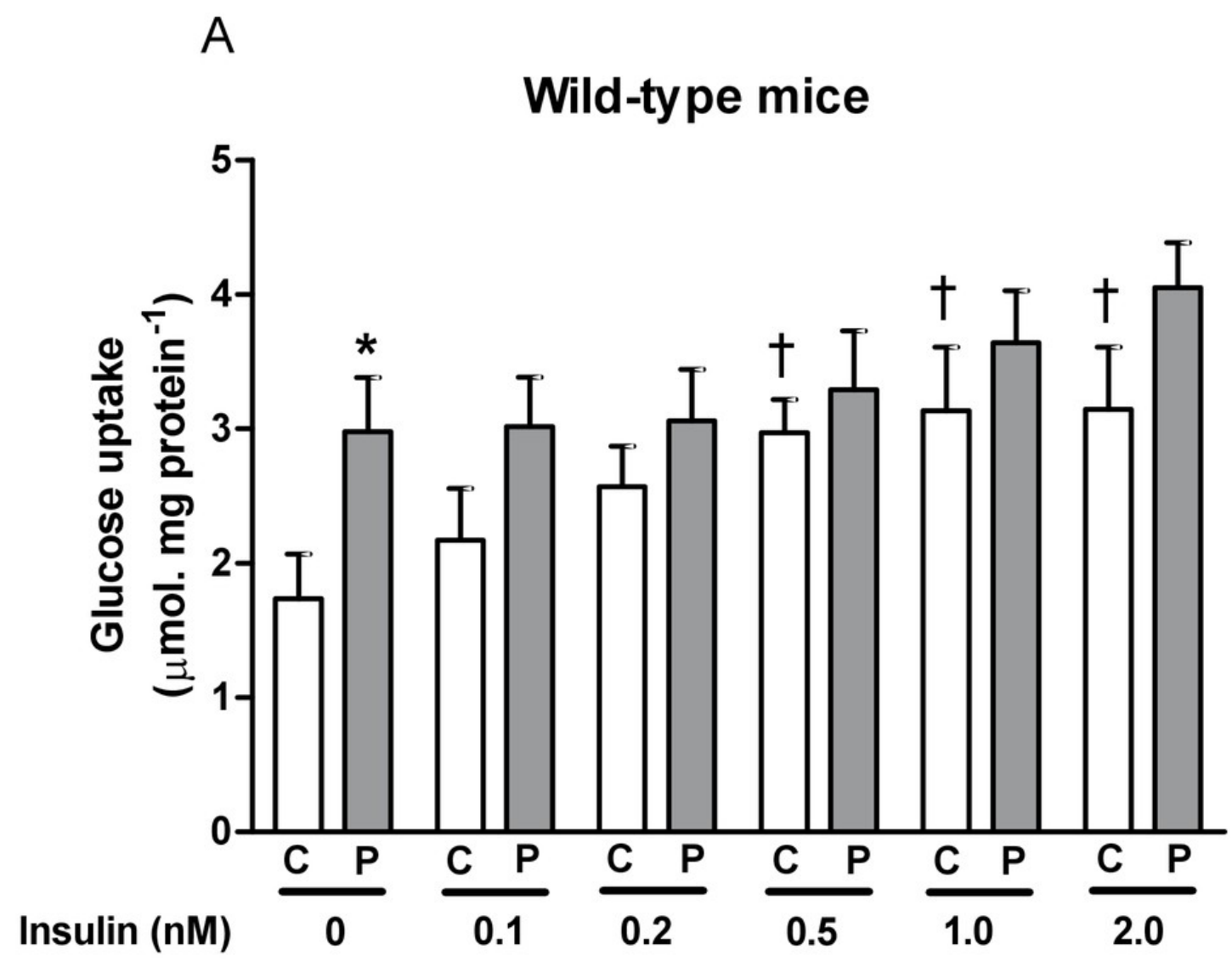

B

Obese mice

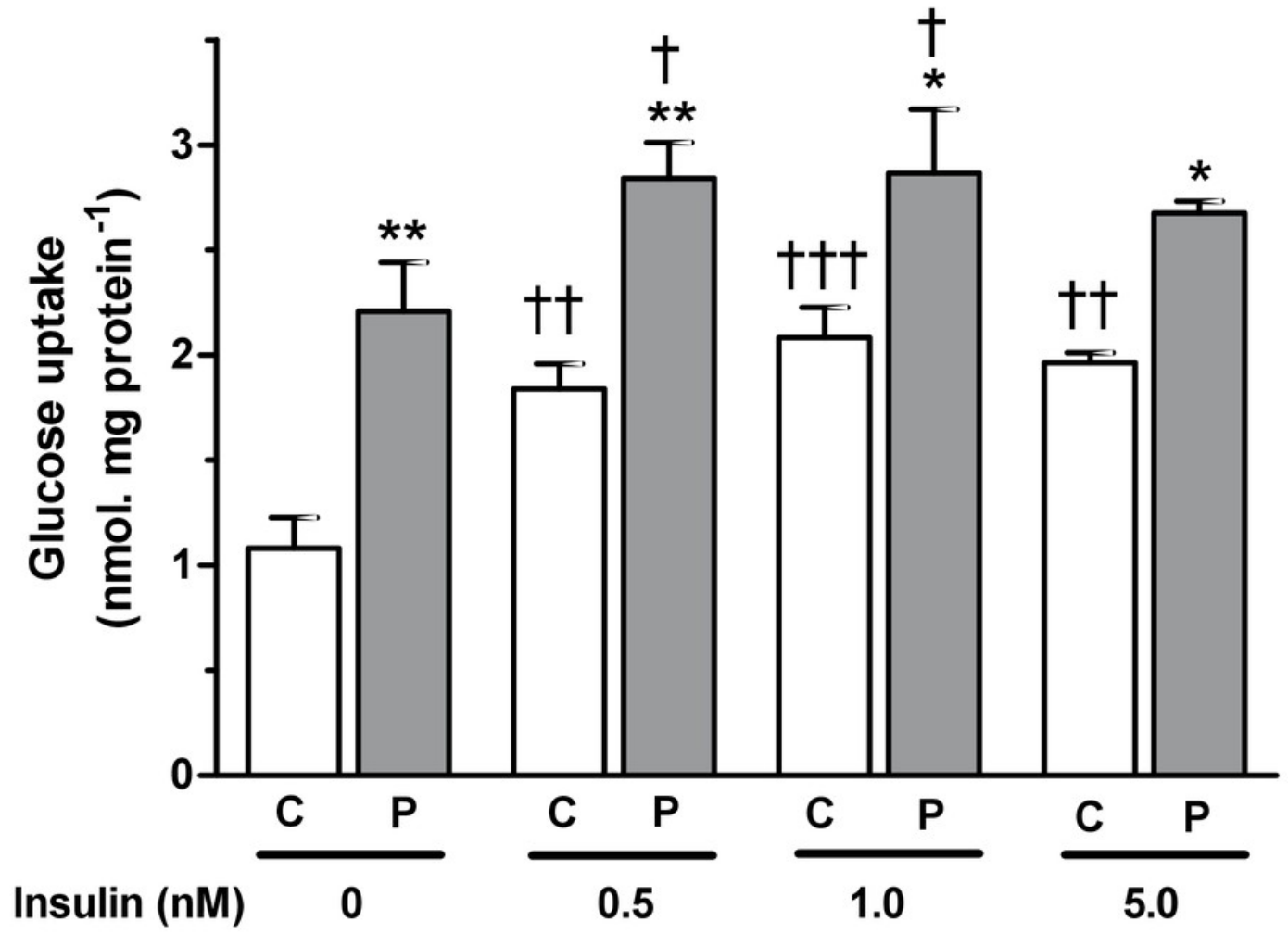




\section{Figure 3}

Concentration-response curve for the effect of PAP-1 on glucose uptake in the absence of insulin in adipocytes of female wild-type C57BI6 mice.

$\mathrm{n}=8$ mice per group for all columns. Data were analyzed by one-way ANOVA followed by Fisher's least significant difference test against the control value. ${ }^{*} P<0.05$; ${ }^{* *} P<0.001$ for effect of PAP-1 compared to baseline.
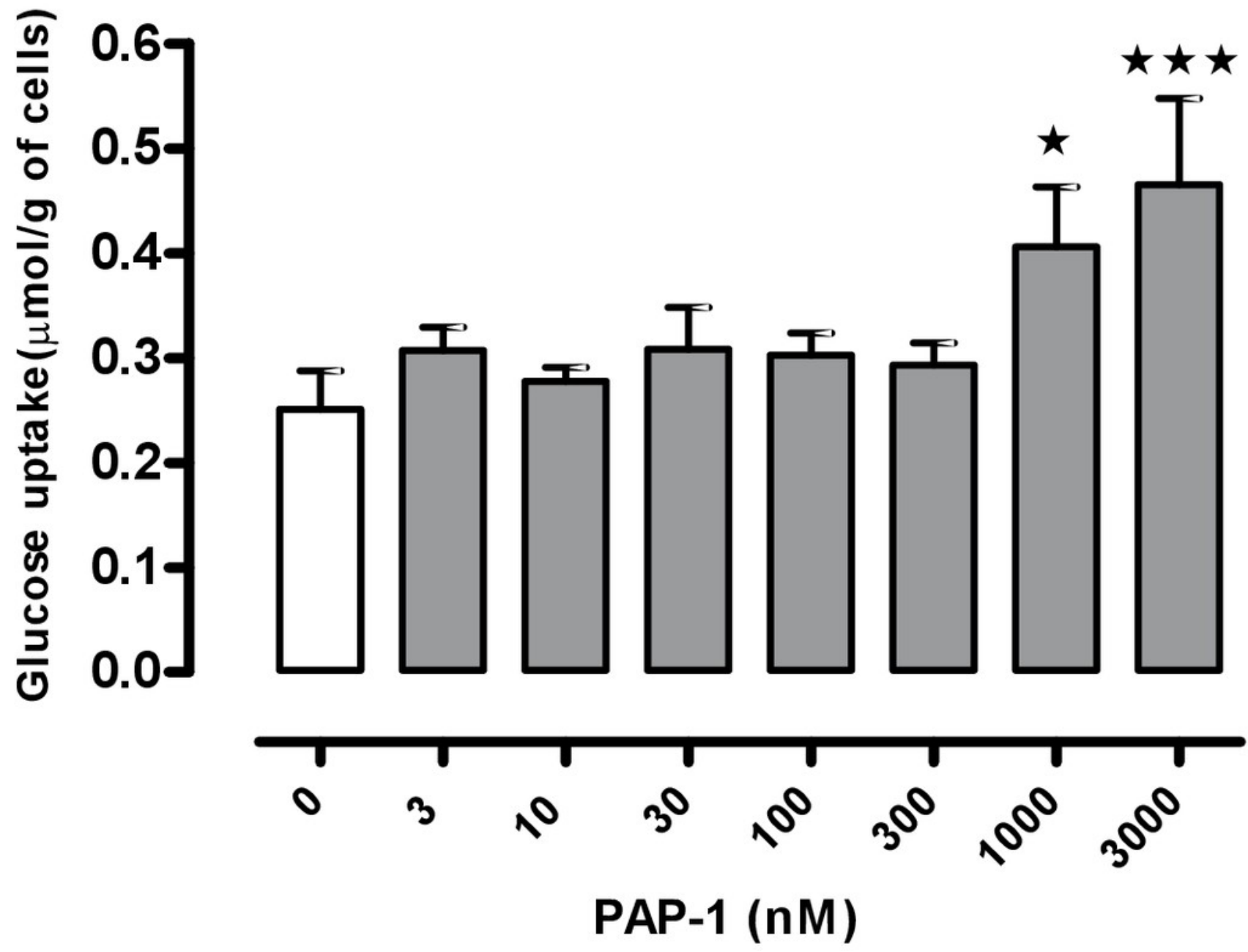


\section{Figure 4}

Effect of PAP-1 (3 microM) on TNF $\alpha$ secretion by adipocytes from female wild-type and ob/ob mice.

$\mathrm{n}=6$ mice per group for all columns. Data were $\log _{10}$-transformed so that variances were not significantly different between groups prior to analysis by two-way ANOVA (sources of variation: genotype and PAP-1 concentration), followed by Fisher's least significant difference test. ${ }^{\star} P<0.05$; ${ }^{* *} P<0.01$ for effect of PAP-1 compared to control (Con).

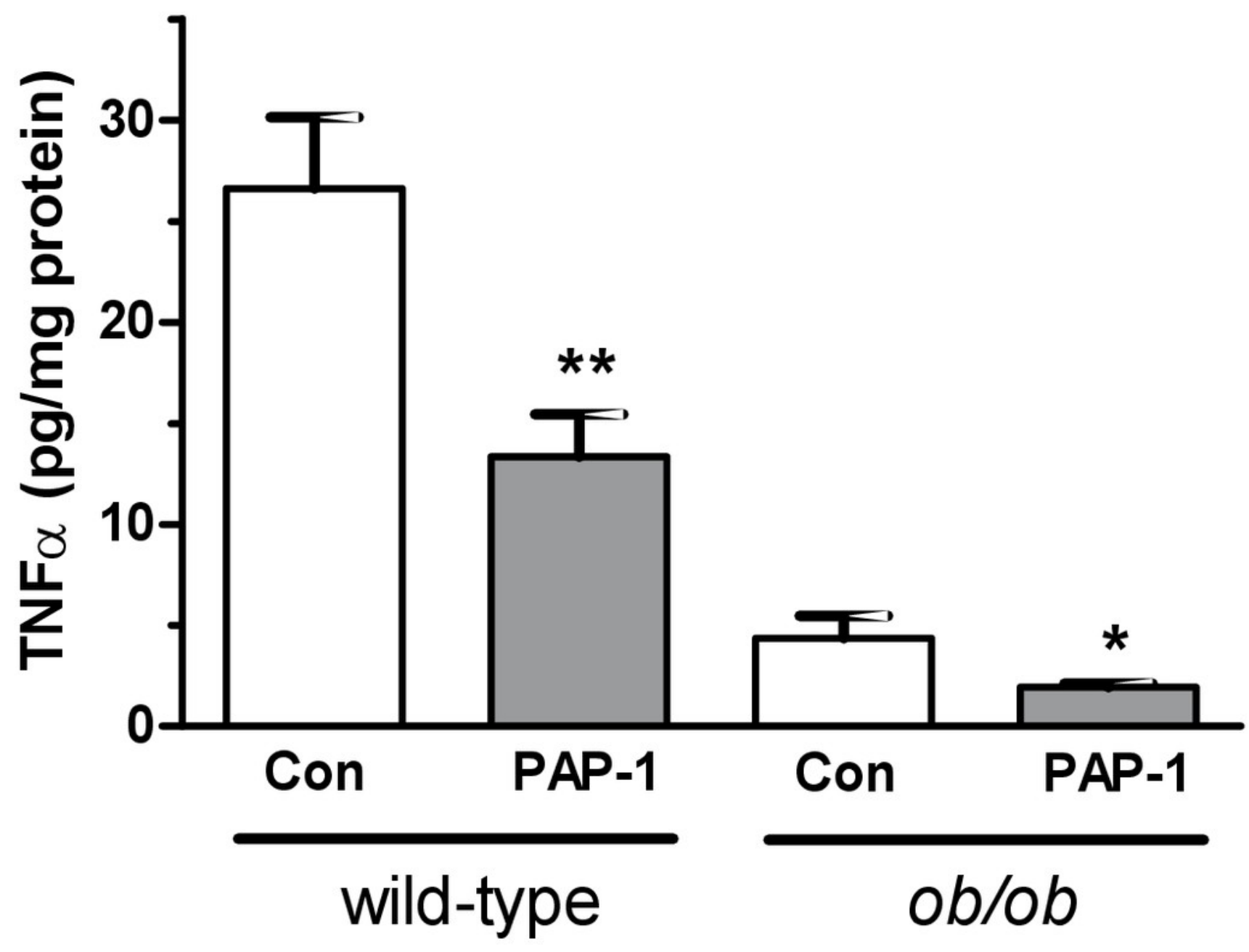




\section{Figure 5}

Kv1.3 and Kv1.5 mRNA levels in liver, gastrocnemius, soleus and white adipose tissue of female $(A)$ wild-type and $(B)$ ob/ob mice.

$\mathrm{n}=3$ mice for all columns. Expression of each potassium channel was calculated relative to expression of GAPDH in each sample. Data were $\log _{10}$-transformed prior to statistical analysis because the data obtained for Fig 6 suggested that widely distributed data did not follow a normal distribution without this transformation. Analysis was by two-way ANOVA (sources of variation: genotype and tissue) for each gene, followed by Fisher's least significant difference test for each pair of wild-type and $o b / o b$ values. Unpaired t-tests conducted on untransformed data gave the same significant differences. ${ }^{\star} P<0.05$; ${ }^{\star \star} P<0.01$; ${ }^{* * \star} P<0.001$ compared to wild-type mice. 

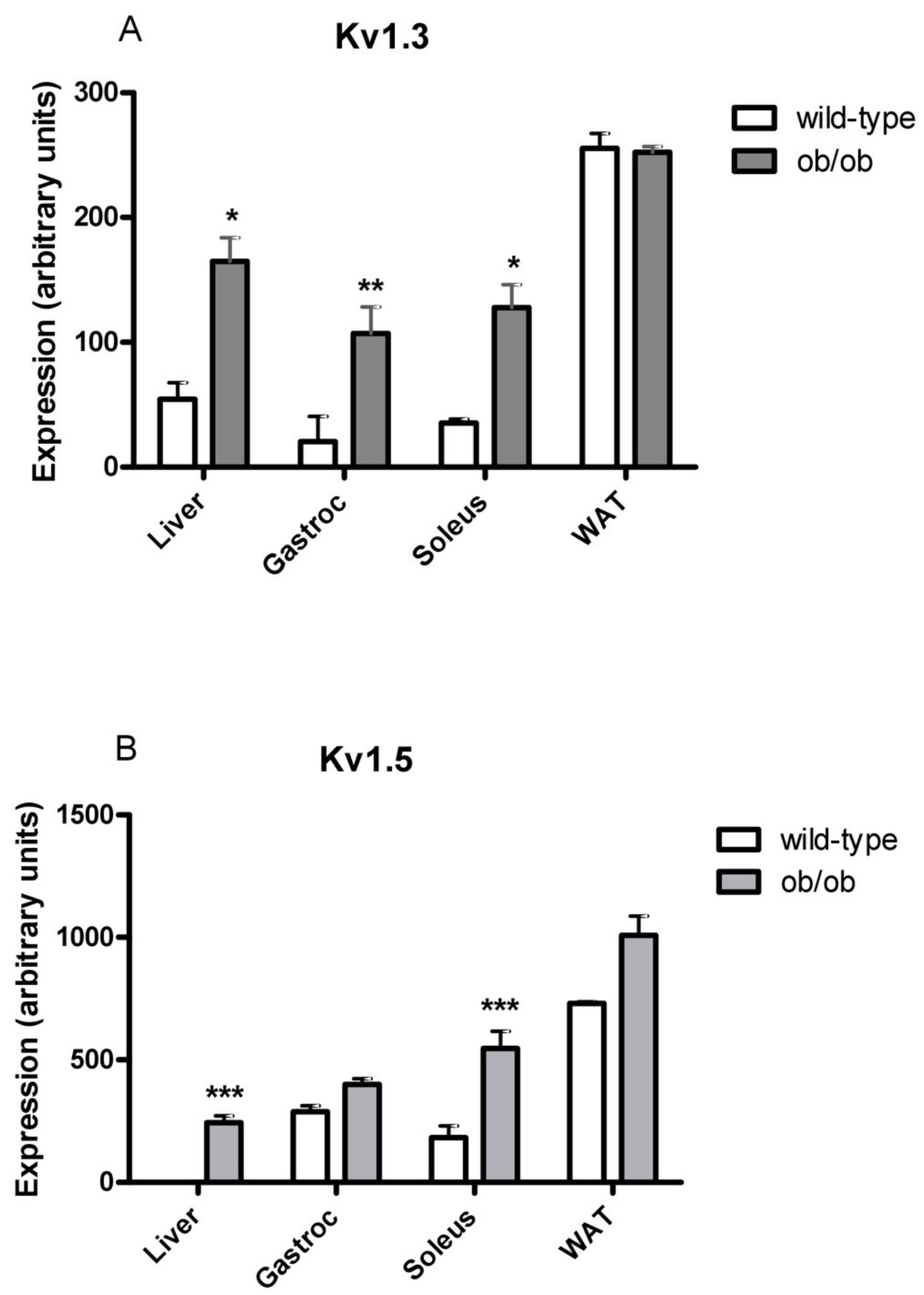


\section{Figure 6}

Relative expressionof Kv1.2, Kv1.3 and Kv1.5 expression in (A) adipose tissue, (B) adipocytes and $(\mathrm{C})$ soleus muscle of wild-type mice.

Relative expression is given assuming that PCR reaction efficiencies were 1.0 for each gene. The expression of each $\mathrm{Kv}$ channel was expressed relative to GAPDH in the same sample and then relative to $\mathrm{Kv1} 1.3 . \Delta \mathrm{C}_{\mathrm{T}} \mathrm{GAPDH}-\Delta \mathrm{C}_{\mathrm{T}} \mathrm{Kv1} .3$ was $4.43 \pm 0.31$ for adipose tissue, $6.32 \pm 0.34$ for adipocytes and $9.8 \pm 0.70$ for soleus muscle $(n=6)$. Data were $\log _{10}$ -transformed prior to statistical analysis because variances were clearly higher for Kv1.5, which was far more highly expressed than Kv1.2 or Kv1.3. Thus the Bartlett and F-tests showed significant differences in variance for the adipose tissue and adipocyte data respectively when these data were not transformed. Analysis was by two-way ANOVA (sources of variation: gene and tissue), followed by Fisher's least significant difference test for adipose tissue and soleus muscle. Kv1.2 was undetectable in adipocytes, so Kv1.3 and Kv1.5 were compared by unpaired t-test. $n=4$ mice for soleus muscle and 6 mice for adipose tissue and adipocytes. ${ }^{* *} P<0.01 ;{ }^{* \star} P<0.001$. 
A

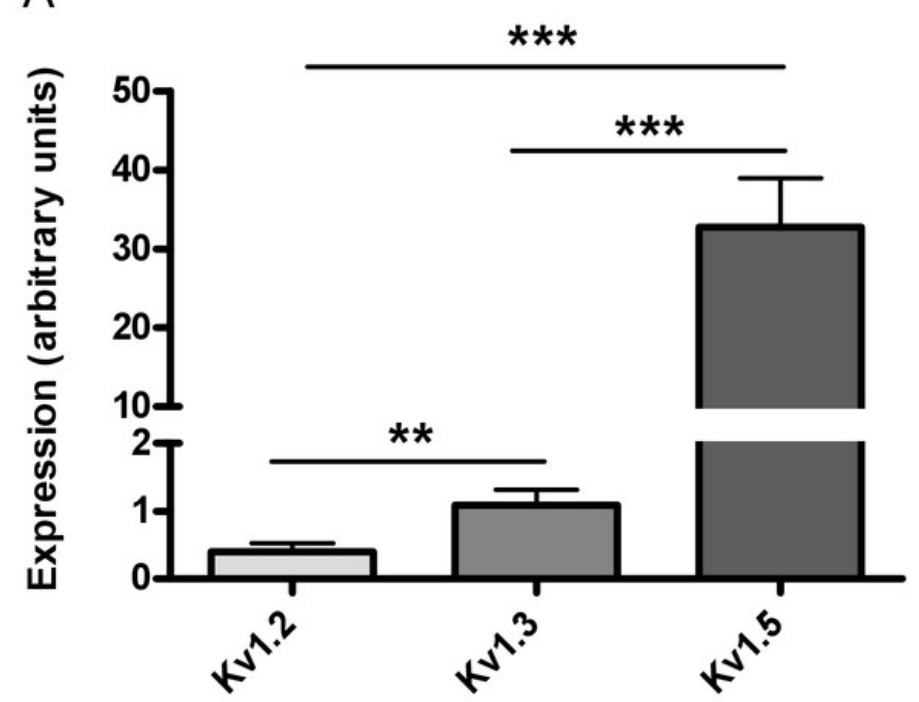

Adipose tissue

B

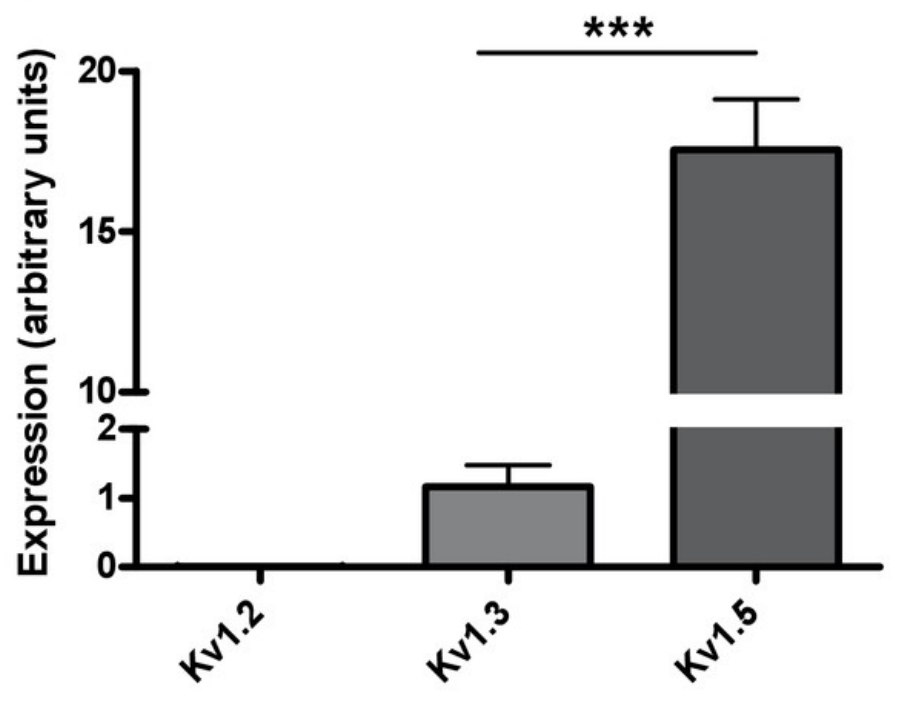

Adipocytes

C

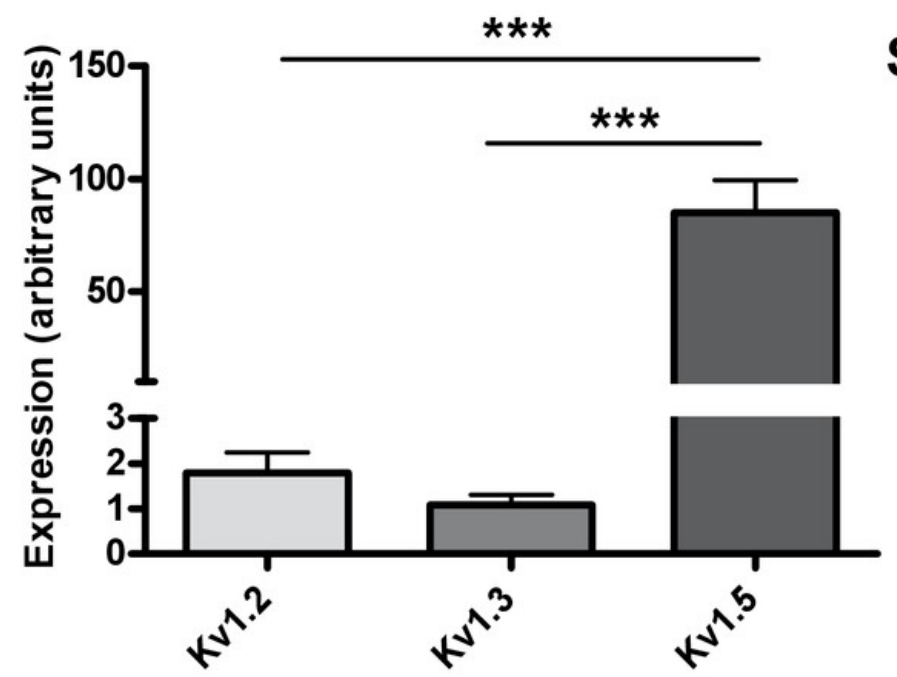

Soleus muscle 